\title{
Comparative Analysis of Factors Affecting Employee Performance According to Job Performance Measurement Method: The Case of Performing Artists*
}

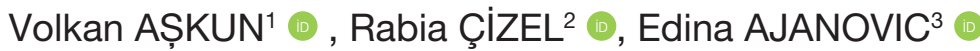

\begin{abstract}
There are many factors that may affect employees' job performance such as psychological, sociological, anthropological, demographic and similar. However, related literature was mainly focusing on psychological and demographic ones, which were often analyzed through different job performance measurement methods such as self-evaluation and supervisor (or superior) evaluation. The main goal of the current study is to define and compare the factors affecting employee's job performance according to the above mentioned measurement methods, as well as their level of importance. For the purpose of this study, data were collected through survey conducted in the Antalya region in Turkey among 305 participants coming from seven countries and consisting of both employees and supervisors working for a performing artists organization company. Data were analyzed by using CHAID analysis through classification algorithms. Results show there is a difference between variables explaining the job performance of the employees when they do self-evaluation of their own performance than when the same is done by their supervisors. Nationality is one of the factors affecting performance in both evaluation forms. While the performance of individuals with extraversion personality traits was high in case of self-evaluation, the performance of the men who were second-born or after was high in the evaluation by the supervisors. These results demonstrated the problematic nature of measuring job performance and making accurate evaluations based on it.
\end{abstract}

Keywords: Individual job performance, personality traits, demographic variables, CHAID analysis, job performance measurement

\section{INTRODUCTION}

Due to its abstract and complex structure, it is impossible to consider individual job performance (IJP) as only a physical indicator, as there is no single indicator comprehensive enough to define such constructs. Thus, this implies that there is no unique and tangible manner to evaluate performance in this context. Often used IJP measurement methods are those based on subjective evaluations and organizational records, which are considered as the objective ones without involving human judgment. Organization records keep track of direct productivity measures expressed in number of units produced and personal data such as absenteeism, work accident, being late on work and similar. Subjective evaluations can be done through rating or ranking by the employees themselves or by their supervisors, subordinates, colleagues, customers, and other related groups. On the other hand, there are different criteria for these assessments. These are "immediate criteria" outlining measured performance over a specified time, "intermediate criteria" made for the defined moment and "ultimate criteria" performance made throughout the whole period of time in the organization (Thorndike, 1949). These criteria can be used in both subjective and objective (organization records-based) evaluation methods. With such a multifaceted and complex assessment structure, it is reasonable to expect that there will be differences between the assessments in the measurement of IJP, depending on the evaluation method.

*This research was supported by Akdeniz University Scientific Research Projects Coordination Unit. Project Number: SYL-2018-3239

'Lecturer, Akdeniz University Demre Dr. Hasan Ünal Vocational School, volkanaskun@gmail.com

2 Professor, Akdeniz University Faculty of Economics and Administrative Sciences, rabiacizel@akdeniz.edu.tr

${ }^{3} \mathrm{PhD}$, Akdeniz University Technocity Talya Software, ajanovic87@gmail.com 
Because of the possible judicial and biased observing situations involved with subjective evaluations, it is possible to prefer measurement based on organizational records due to its advantage of storing numerical values. However, inefficient use of the three above mentioned criteria or risk of manipulation can negatively affect the validity of the organizational records as well. In light of these assumptions, companies tend to use and benefit from both types of performance measurements (Bracken, Rose \& Church, 2016). Nevertheless, in the literature, there are low relationships between subjective evaluations such as grading and ranking in which evaluations are performed in the form of employee-himself, customer, subordinate, parent, colleague, and 360-degree.

When analyzing studies in the field of IJP, it can be stated that the correlation analysis between various evaluation methods was in focus. According to meta-analysis study conducted by Harris and Schaubroeck (1988), low correlation of 0.35 between self-evaluation, evaluations from colleagues and supervisors was observed. Similarly, meta-analysis studies conducted by Conway and Huffcutt (1997), and Heidemeier and Moser (2009) both showed correlation of 0.22 between these different evaluation methods, emphasizing the problematic nature and importance of this topic in the academic field. According to knowledge of the researchers, analytical methods such as CHAID analysis using classification and segmentation processes in decision trees are lacking in the field of IJP.

Nowadays in many organizations employee's low performance brings high damages to the employee himself/herself, to the working team and overall company, causing decline in the global economy and organizational liquidation. Due to the broad impact on these areas, realistic measurements of IJPs of the employees have become a matter of great importance. Therefore, the current study is conducted with the goal to define and compare the factors affecting employee's job performance according to the self-evaluation and supervisor measurement methods, as well as the level of importance of these factors. It is considered that the study conducted in this manner will have several contributions. The first one is the fact that the current study is conducted among participants of different nationalities where the effect of this variable is tested together with other demographic variables of co-workers in the same organization. Second, this study provides another perspective on the relational studies between IJP and personality. Finally, it elaborates on how different anal- ytical methods, such as CHAID analysis and algorithms, can contribute to the study on IJP. In this context, the study aimed to investigate the variables that predict performance and their severity according to different measurement methods.

In the first part of this paper, literature review on definitions, dimensions, and indicators of individual job performance measurement will be presented together with references to several evaluation models discussed in the field. Second part of the literature review will be devoted to revision of the studies that had the effect of several demographic and psychological factors on IJP in their focus. Current paper will continue with the description of the methodology approach adopted in answering to research questions, followed by the presentation of the study results. Lastly, discussion of the obtained results, as well as final conclusions on theoretical and practical implications of the current study will be provided.

\section{LITERATURE REVIEW}

\subsection{Defining and Measuring Job Performance}

Job performance is defined as behaviors related to meeting expected, identified or formal role requirements of organization members (Campbell, 1990). The important element of this definition is that performance is the characteristic of group or individual behavior that occurs during a certain period of time. Defining and understanding the basic structure of individual job performance (IJP) have represented a very interesting topic in industrial and organizational psychology field. First of all, IJP is important because of the ongoing globalization of the economy. It represents one of the basic indicators of working groups' and company's performance and it significantly contributes to company's efficiency and competitiveness (Koopmans, 2014). On the other hand, industry and organization psychologists were interested in investigating the effects of determinants such as participation, satisfaction, and personality on IJP (Judge, Bono, Thoreson \& Patton, 2001).

Generally, it is assumed that IJP differs from one job to another. Evaluations of IJP found in the literature were mainly focused on objective criteria of job productivity or on the qualitative and quantitative judgments taken by the employee himself/herself, his/her colleagues or supervisors. Job performance can be considered as an abstract, hidden structure that cannot be directly marked or measured. It consists of multiple components or dimensions which further include directly 
measurable indicators. In order to conceptualize and functionalize the IJP area, it is necessary to describe and define dimensions and indicators of this performance in organizational settings. While dimensions can be generalizable, full list of indicators may vary between jobs.

Conceptualization of job performance received considerable attention in psychology field. Viswesvaran and Ones (2000) defined IJP as employees' connection or contribution to organizational goals or measurable actions, behaviors and outcomes. It is important to make a difference between causal variables and indicators of job performance. While causal variables serve to define or predict one's job performance, indicators are considered as reflections of this performance (Fayer \& Hand, 2002). For example, while job satisfaction is regarded as determinant of job performance, job quality is seen as its indicator.

Based on the conceptual classification of IJP dimension found in the literature, four broad dimensions can be proposed (Sinclair \& Tucker, 2006; Koopmans, Hildebrandt, Buuren, Van der Beek, \& De Vet, 2013, Hashmi, Ameen \& Soroya, 2019; Nadatien, Handoyo, Pudjirahardjo \& Probowati, 2019, Dåderman, Ingelgård \& Koopmans, 2020): task performance, contextual performance, adaptive performance and counterproductive work behavior. The first dimension, task performance, is about which central work tasks should be performed. Contextual performance expresses the behaviors that support the organizational, social and psychological environment in which the technical core should function. Adaptive performance, as a third dimension, was added to cognitive framework. Adaptive performance refers to employee's ability to adapt to the changes that may occur to the organizational working system or working role. Sinclair and Tucker (2006) provided social, conceptual, and empirical reasons for distinguishing adaptive performance as a separate dimension. Final dimension, counterproductive work behavior, assumes all types of behavior that may damage welfare of the organization. Proactive and creative performance were considered as two separate dimensions. Although proactive and creative performance can be considered as a part of task performance for some jobs, these categories are assumed to be more appropriate to contextual performance due to their contribution to a positive organizational, social, and psychological work environment (Viswesvaran, 2002).

Allen (2008) and Escorpizo (2008) were focused on only counterproductive work behavior dimension, more specifically, to presenteeism and absenteeism categories. On the other hand, Hassan, Nevo and Wade (2015), examined innovative job performance, habit and cognitive and relational social capital under the contextual performance. Most of the previous studies were focusing on task and contextual performance dimensions (Aboagye, Dai \& Bakpa, 2020; Akca \& Yurtcu, 2017; Uppal,2014; Alfes,Truss, Soane, Rees \& Gatenby, 2013; Mael, O'Shea, Smith, Burling, Carman, \& Haas, 2010; Tett, Guterman, Bleier \& Murphy, 2000; Borman \& Motowidlo, 1993, Zhao, Liu \& Zhou, 2020). However, some of these studies were examining these dimensions in relation to organizational citizenship behavior, managerial behavior, developing self and others, orientation, reliability, professional intelligence, emotional control and communication.

The most prominent among contemporary used frameworks in measuring IJP is the one by Campbell, McHenry and Wise (1990) who proposed eight performance components: job-specific task proficiency, non-specific task proficiency, written and oral communication, effort, maintaining personal discipline, facilitating peer and team performance, supervision/ leadership, and administration/management. Generally, this study created an infrastructure for the measurement of IJP. Furthermore, a set of interconnected frameworks focusing on various forms of behavior such as citizenship behavior (Smith, Organ \& Near, 1983), social behavior (Brief \& Motowidlo, 1986) and contextual performance (Borman \& Motowidlo, 1993) can be traced in the related literature. What is common for most of these frameworks is that they focus on positive behaviors that contribute to organizational effectiveness, while these do not reflect basic work tasks. These positive behaviors include helping others, persevering and making extra efforts and supporting the organization. Although there are differences of these frameworks in terms of their focus, the areas of covered behavior are largely overlapping. This was supported by the literature which differentiates and compares the field of task performance and the field of citizenship / pro-social / contextual performance (Motowidlo \& Van Scotter, 1994).

By adding counter productive work behavior domain in his study, Allen (2008) allowed for a broader understanding and effectiveness of the three main areas of performance, finalizing the definition of a heuristic framework of the IJP consisting of four dimensions: task performance, contextual performance, adaptive performance, and counter productive work behavior. 
These four dimensions can be considered to capture all forms of behavior that define the IJP in almost every job.

In the field of work and organizational psychology, traditionally the main focus of the IJP structure is on task performance which can be defined as the individual's competence to perform basic or technical tasks central for his/her work. In addition to task performance, the IJP structure consists of contextual performance, adaptive performance, and counterproductive work behavior, which should also be examined when trying to assess individual's job performance. Accordingly, work and organizational psychologists have developed numerous scales (Van Scotter\&Motowidlo, 1996; Bennett \& Robinson, 2000; Podsakoff \&MacKenzie, 1989), to measure task performance, contextual performance, adaptive performance, or counterproductive work behavior.

Despite its importance and popularity, it is hard to reach compromise on how to define and measure the IJP. Naturally, there are many tools available to measure the IJP or related structures, but after analyzing the studies of IJP in different research areas, it can be seen a lack of a clear definition and conceptual framework. This prevents the creation of precise measurements for assessing this topic. As a result, it is difficult to establish the effectiveness of interventions, procedures and strategies to maintain, improve or optimize the IJP. Current study hopes to benefit greatly from a short, but comprehensive, measurement scale in order to address this structure.

\subsection{Factors Affecting Job Performance}

There are numerous factors affecting job performance. One of them is personality. Personality plays an important role in defining how an individual will behave in different situations (Yeşilyaprak, 2012). Personality can be defined as the pattern of characteristics and behaviors that reflect the unique arrangements of the individual towards his/her environment. Main characteristics include interests, values, motivations, attitudes, "self" concept, abilities, behavioral, and emotional patterns. All of these factors are affecting job performance (Craik, 1993). In some of the studies that were investigating the relationship between personality characteristics and performance, a direct relationship between these two variables was found (Barrick, Mount \&Strauss, 1993). Blickle (1996), proposed that there are many work situations were only the effort itself will be efficient and enough for satisfactory performance, but also many others where, solely, the same effort will not be sufficient. One person can work for many hours and may be in a situation where he/she has to make various decisions. Despite all the time spent at work, he/she may be using ineffective strategies and may not work as well as someone who makes the right decisions and uses the right strategies. These propositions are constantly being expanded in order to understand personality as an important predictor of IJP (Pallegama, Ariyasinghe \& Perera, 2007) with the tendency for a continuous research on personality-performance relation.

In order to obtain more information about characteristics and actions from a broader perspective, Mumford and Gustafson (1988) focused on three points of relationship between personality traits and performance. First, personality traits may facilitate or prevent the effective use of strategies. In addition, personality may create motivational effect for performance increase. Finally, success or failure of an individual can be attributed to the personality traits. These situations, especially related to decision-making, are important to understand how personality causes different behavioral patterns leading to variations in job performance. In general, personality theories are discussed from psychodynamic, humanistic, social-cognitive and trait perspectives. From the trait perspective, several theories were proposed such as: trait theory (Allport, 1966), factor analytic trait theory (Cattel, 1979), the Big Five personality traits theory (Costa \& McCrea, 1992) and biological traits theory (Eysenck, 1967). Eysenck's three-dimensional biology traits theory is one of the most often used theories, especially among employees of different culture. This is proven by its application in more than 35 countries such as the USA, Sweden, China, Nigeria, Japan etc. (Schultz \& Schultz, 2017). Biological traits theory was applied in the current study because the order of birth was among examined variables and because it also comprises the 'lie'sub-dimension, used to test how honest and sincere the respondents were while evaluating items in the research questionnaire.

Studies from the related literature found a negative correlation between neuroticism, psychotism and IJP, and a positive correlation between extraversion and IJP (Rothmann \& Coetzer, 2003; Premuzic \& Furnham, 2003; Poropat, 2011; Gözel, Atmaca, \& Durat, 2017). According to these studies people with neuroticism tendency are weaker and less creative than those who are emotionally determined. At the same time, positive effects of extraversion tendencies in relation to task performance and creativity were put forward. 
Social scientists have examined the relation between birth order and various outcomes for more than a hundred years (Galton, 1874). Results of the conducted studies showed that the first-born children have tendency to reach more resource, attention and higher level of cognitive warnings (Hertwig, Davis, \& Sulloway, 2002; Price, 2008). First-born child enters into interaction with parents alone and he/she is exposed to an environment with comparatively higher level of cognitive maturity. On the other hand, second-born child interacts both with parents and elder siblings which means that the level of cognitive warning is lower on average. There are empirical evidences showing that later-born children have lower success in education and cognitive development (Barclay, 2015). In addition, focus of research studies in this context was on examining the relationship between individual's birth order, intellectual development and educational outcomes. Time parents spend with the children, mother's age and educational level, as well as the fact that the child was the first born in the family were considered as effective factors on the future outcomes of the child's life. According to the study conducted in Norway among the fifth-grade students, where the relation between academic performance and birth order was measured (Bonesrønning \& Massih, 2011), results showed that with families that have more than one child, first-borns had the significant advantage. There are additional studies proving that first-born children are better in academic performance (lacovou, 2008).

Besides personality and birth order, gender was also examined as a factor with potential influence on job performance. In the study conducted in the Turkish city of Diyarbakir among 320 participants, Demirok (2018) found that there is no significant difference in IJP according to gender. In the same way, Keleş (2017) has not detected difference between gender and IJP on 122 people in the study conducted in another
Turkish city-Sivas. Finally, in one study conducted in international company in Japan with 643 participants (Sekiguchi, Bebenroth, \& Li, 2011) and in another one with 300 American and Lebanese participants (Diab \& Hazer, 2012), the significant difference between nationality and IJP was found.

The goal of the above-mentioned literature review was to define the dimensions of IJP and to review different methods of its evaluation. In addition, it examines the relation between dependent variable such as IJP and independent variables such as psychological and demographic factors. What have not been discussed in the previous literature yet is the adequate clustering of these independent variables and their level of importance on IJP. Guided by the following research questions, current study tries to address this literature gap.

1. Is there a difference between the performance averages of the employees according to the performance evaluation method (the self-evaluations and supervisor's evaluations)?

2. How are employees classified according to independent variables (personality traits and demographic traits) in terms of their performance?

3. What is the importance of independent variables in classifying employees in terms of their performance?

4. Does the effect and significance of the independent variables change in the classification of employees in terms of their performance according to the performance evaluation method (self-evaluations and supervisors' evaluations)?

Figure 1 illustrates the research design adopted in the current study. Further explanation of the adopted research method will be presented in the continuation.

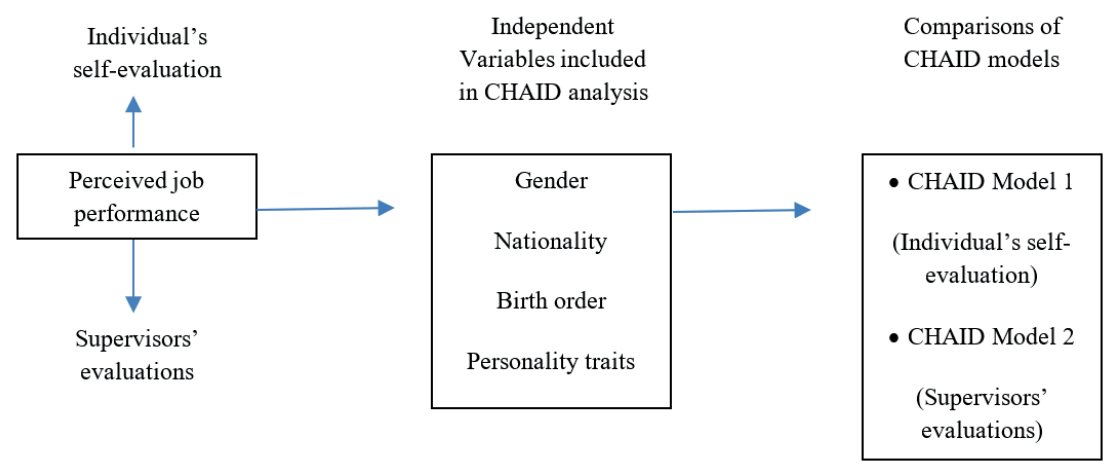

Figure 1: Study Research Model 


\section{METHOD}

The study group consists of stage performers of different nationalities who are employed in performing arts organization company operating in Turkish city of Antalya. Antalya is a well-known touristic region which attracted more than 12,5 million international visitors in 2018 (TUROFED, 2019). Besides sun, sand and beach tourism concept, there are a lot of opportunities to involve in alternative tourism forms in the area. In this manner, various types of events and show performances are taking place throughout the region, such as Adrenalin shows, which are able to attract attention among both tourists and local community. Due to the increased interest in these events and benefits they may have on various stakeholders in the area, it is important to pay attention to the performance of the artists as they have a vital role for a successful show. This is the reason why this group of employees was selected for the current study.

Prior to conducting a research, necessary permissions were obtained and, in total, 305 foreign employees coming from seven countries working in three different companies voluntarily accepted to participate in the study. The three companies in the study were selected according to their ability to perform in ultra luxury five star hotels in Antalya. In the current study quantitative method was used and data were collected through questionnaires that were distributed between February to April 2018 in English, Russian and Spanish. Items of the measurement scale in the questionnaire were composed based on the reviewed literature. In addition to demographic questions "Individual Job Performance Survey" and for personality traits "Eysenck Personality Survey" was used. Employees' performance was evaluated in two methods (self and supervisor's evaluations). For performance measurement, scale proposed by Koopmans et.al (2013) was used. Validity and reliability of the measurement was empirically tested by several studies (Abubakar, Pangil, \& Othman, 2016; Ceschi, Sartori, Dickert, \& Costantini, 2016, Metin, Peeters, \& Taris, 2018). All of the items included in the measurement tool used for performance measurement are scored in the 5-point Likert type with Strongly Agree $=5$, Agree $=4$, Neutral = 3, Disagree $=2$, and Strongly Disagree $=1$.

In the study, the reliability coefficient (Cronbach's alpha) of the 23-item scale used for performance measurement was determined to be 0.93 . In the validity study of the scale, explanatory factor analysis was applied to the items. According to these results, it was found that the 23-item subscale had a five-factor structure and $66.189 \%$ of the total variance was explained by the scale items. After conducted factor analysis, the following statements were being removed from the proposed structure due to the fact that these disrupt factor structure: under "interpersonal performance" dimension P6 number I take the initiative at my job, "adaptive performance" dimension P14 number - $I$ show resistance to stress and tough situations and $\mathrm{P} 17$ number - I keep my business skills up to date.

When analyzing Table 1, it can be concluded that "task performance" dimension has the highest variance explanation rate with \%17.998. Dimension with the least variance explanation rate is counterproductive work behavior with \%9.387. As can be seen from Table 1 , the total variance explanation rate of the IJP scale is $66.189 \%$.

In the current study, Eysenck Personality Questionnaire was used to measure the personality characteristics. First time it was used by the Francis, Brown, and Philipchalk (1992), while reliability and validity of this measurement was tested in several future studies (Sato, 2005; Maltby, Talley, Cooper \& Leslie, 1995; Karancı, Dirik \& Yorulmaz 2007). This measurement scale consists of 24 items of four factors structure (extraversion, neuroticism, psychoticism and lie). The lying subscale is intended to prevent bias during the implementation of the questionnaire and to check its validity. In this questionnaire, where each factor was evaluated with six items, participants were asked to answer 24 questions in the format Yes (1) - No (0). The score for each personality trait varies from 0 to 6 .

Lie dimension in Table 2 was used as a sub dimension in order to test how honestly and sincerely the items in the questionnaire were answered. These sub-dimensions question the behaviors that are assumed to be socially / morally wrong, but can be seen from time to time, and therefore also reflect and trigger sensitivity to social desirability (Karancı et. al, 2007). In this sense, one is able to question the behaviors that are thought to be morally wrong but that are possible for everyone in general. In the current study, higher scores indicate the desire of participants to reflect themselves more positively. It shows the probability of having personality above 3.00 in scores taken between 1-6. As can be seen in Table 2, the lie subscale was the highest at 1.00 . This result shows that participants do not try to show themselves differently in terms of evaluating behaviors that everyone can exhibit, but which is supposed to be morally wrong on a global 
level. They do not have any thoughts about reflecting themselves more positively in other dimensions, which can be interpreted as giving closest answers to reality. The Kuder-Richardson 20 method was used to measure reliability because the items of the 24-item personality inventory were evaluated with the dual answer option and there were no continuous variables (Gliner, Morgan \& Leech, 2017).

Table 1: Factor Analysis Results for IJP Measurement

\begin{tabular}{|c|c|c|c|c|c|c|}
\hline \multicolumn{7}{|c|}{ 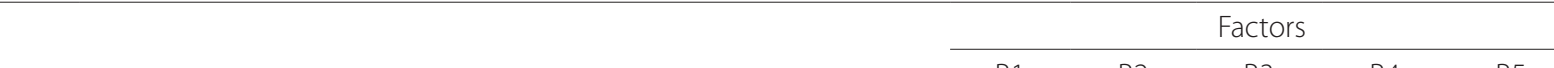 } \\
\hline & & B1 & B2 & B3 & B4 & B5 \\
\hline & \multicolumn{6}{|l|}{ Task Performance } \\
\hline P1 & I am doing a high quality job. & .723 & & & & \\
\hline P2 & I am making a good plan and organization of my job & 656 & & & & \\
\hline P3 & In my job I am result oriented. & 624 & & & & \\
\hline P4 & My job is a priority for me. & .724 & & & & \\
\hline \multirow[t]{2}{*}{ P5 } & I work at my job efficiently. & 618 & & & & \\
\hline & Interpersonal Performance & & & & & \\
\hline P7 & I accept the feedback of the job I have done and I learn from it. & & .573 & & & \\
\hline P8 & I collaborate with my managers and colleagues. & & .813 & & & \\
\hline \multirow[t]{2}{*}{ P9 } & $\begin{array}{l}\text { I establish effective communication with my managers and } \\
\text { colleagues. }\end{array}$ & & .790 & & & \\
\hline & Organizational Performance & & & & & \\
\hline P10 & I take the responsibility for the work I do. & & & 642 & & \\
\hline P11 & I am customer-oriented at my job. & & & .492 & & \\
\hline P12 & I am creative at my job. & & & .579 & & \\
\hline \multirow[t]{2}{*}{ P13 } & I accept hard tasks at my job. & & & .625 & & \\
\hline & Adaptive Performance & & & & & \\
\hline P15 & I find creative solution for new and hard problems. & & & & .550 & \\
\hline P16 & I keep my job-related information up-to-dated. & & & & .513 & \\
\hline P18 & I can cope with unknown and unpredictable work situations. & & & & 691 & \\
\hline \multirow[t]{2}{*}{ P19 } & I can adjust my working goals when needed. & & & & .744 & \\
\hline & Counterproductive Work Behavior & & & & & \\
\hline P20 & $\begin{array}{l}\text { I do not show negative behavior at my job (complaining, } \\
\text { exaggerating my problems etc.) }\end{array}$ & & & & & .600 \\
\hline P21 & $\begin{array}{l}\text { I do not involve in behavior that can harm my working place } \\
\text { (disobeying the rules, revealing secret information. etc.) }\end{array}$ & & & & & .786 \\
\hline P22 & I do not do anything that can harm my colleagues and managers. & & & & & .800 \\
\hline \multirow[t]{6}{*}{ P23 } & I do not intentionally make mistakes at my job. & & & & & .697 \\
\hline & Eigenvalues & 3.598 & 2.954 & 2.487 & 2.322 & 1.877 \\
\hline & Variance description rate (\%) & 17.998 & 14.770 & 12.434 & 11.611 & 9.387 \\
\hline & Cumulative Variance (\%) & 17.998 & 32.758 & 45.192 & 56.803 & 66.189 \\
\hline & $\mathrm{KMO}$ & & & .917 & & \\
\hline & Bartlett'Test & & & 2895.026 & & \\
\hline
\end{tabular}

Table 2: Eysenck Descriptive Statistics of Personality Questionnaire

\begin{tabular}{lllll}
\hline & $\begin{array}{l}\text { The } \\
\text { Lowest }\end{array}$ & $\begin{array}{l}\text { The } \\
\text { Highest }\end{array}$ & Average & SD \\
\hline Extraversion & 1,00 & 6,00 & 4,16 & 1,56 \\
\hline Neuroticism & 0,00 & 6,00 & 1,73 & 1,60 \\
\hline Psychoticism & 0,00 & 6,00 & 1,68 & 1,14 \\
\hline Lie & 0,00 & 1,00 & 0,65 & 0,27 \\
\hline
\end{tabular}

Kuder-Richardson alfa values were presented with extraversion, psychoticism and neuroticism dimensions having the $0.71,0.66,0.68$ values respectively. Reliability of each dimension is above 0.60 and is being under certain limitations.

In the continuation of the study CHAID analysis was used in order to examine the variables that are effective in the classification of employees in terms of their 
performance according to the evaluation method. In accordance with the research goal, CHAID analysis was used to determine the relative effects and significance of independent variables on the IJP, which was determined as dependent variable. The reason for using decision tree methods, such as CHAID analysis, is the possibility to easily observe the order of significance of the predictor variables on the dependent variable. In addition, it allows for derivation of clear and understandable visual structures of the examined variables. With the help of CHAID analysis, it is possible to determine how stage performers are classified according to their personality characteristics, gender, nationality, marital status, order of birth, and the importance of each independent variable on the dependent one. Besides, frequency and percentage values related to the classification of the independent variables and the stage at which the classification will end are given.

\section{RESULTS}

Among 305 participants coming from seven different countries and working in a performing arts organization companies, $41.96 \%$ of the participants are female ( $\mathrm{n}$ $=128)$ and $58.04 \%$ are male $(n=177)$. When looking at the employees nationalities $59.34 \%$ are from Ukraine $(n=181), 17.7 \%$ are from Russia $(n=54), 10.49 \%$ from Columbia ( $n=32), 8.85 \%$ from Cuba ( $n=27), \% 1.64$ from Ethiopia $(n=5)$ and Italy $(n=3)$ and Uzbekistan $(n=3)$ with $0.98 \%$ rate each. When looking at the birth order, $54.1 \%$ of participants are first-born children of whom 68 female and 97 male, while from the $45.9 \%$ of the later-born children 60 were female and 80 are male. In addition, it will be suitable to emphasize that 165 of the first-born individuals 42 female and 55 male in total 97 were the only child.

t-test was used to examine the difference between two performance evaluation models. Based on the data presented in Table 3, it can be concluded that there is a significant difference $(p<.001)$ between employee's self-evaluation of performance than the one done by supervisors. Results showed that employees tend to score their performance higher than their supervisors.

In the study, the overall average of the IJP $(\bar{x}=4.24)$ was taken and this value was determined as the cut-off score, the ones above the average were classified as 1 for success and those below the average were categorized as 0 . In the study, variables such as personality traits, gender, nationality, marital status, and birth order were categorically included as independent variables.
Table 3: $t$ Test Results According to Performance Evaluations Models

\begin{tabular}{|c|c|c|c|c|c|c|}
\hline $\begin{array}{l}\text { Performance } \\
\text { Average }\end{array}$ & $\mathrm{N}$ & $\bar{x}$ & $S$ & $\mathrm{Sd}$ & $\mathrm{T}$ & $p$ \\
\hline $\begin{array}{l}\text { Self- } \\
\text { evaluations }\end{array}$ & 305 & 4,24 & 0,497 & \multirow{2}{*}{608} & \multirow{2}{*}{2,432} & \multirow{2}{*}{, $001^{*}$} \\
\hline $\begin{array}{l}\text { Supervisors' } \\
\text { evaluations }\end{array}$ & 305 & 4,13 & 0,598 & & & \\
\hline
\end{tabular}

${ }^{*} p<.001$

Important assumptions of many statistical methods such as normality, linearity, homogeneity of variance are not of the same significance in CHAID analysis. At the same time, although the CHAID analysis collects the missing values in a separate group, a regression equation to be obtained by this analysis is kept independent of the known classical assumptions since it can divide the whole universe into stable sub-nodes with a mean shift algorithm (Horner, Fireman \& Wang, 2010). Statistical test used in CHAID analysis depends on the target variable or dependent variable: if it is continuous $F$ and if it is categorical chi-square $(x 2)$. The assumption required in CHAID analysis is to specify the scale types for the variables used. In addition, for categorical variables, it is necessary to specify how many categories the target variable is divided into and what these are. The limitation of the analysis is that the dependent variable should be categorical (Aksu \& Güzeller, 2016). In the current study, all dependent and independent variables are categorical variables. Personality types were analyzed in three categories.

Results of the CHAID analysis model were summarized in Table 4. According to this, while IJP is dependent variable, personality characteristics, gender, nationality, marital status, and birth order are independent variables. In the first CHAID analysis IJP evaluation is based on employee's self-evaluations. In case when an individual evaluates his / her own work performance, it is determined that only the nationality and personality type as independent variables are included in the analysis as these significantly predicts the individual's job performance.

As can be seen in Table 4, 40 of the 146 individuals $(27.40 \%)$ with low IJP were correctly classified by the program, but $106(72.60 \%)$ were classified as high performances despite the fact that they were actually low performers. Similarly, 17 of the 159 high-performing individuals (10.69\%) were classified as low, despite their high performance. In this study, it is seen that overall success percentage in the classification of high and low performance employees is $59.7 \%$. The risk value of the study in addition to the classification table was determined to be $40.3 \%$. 
Table 4: Classification Table Regarding IJP Status

\begin{tabular}{|c|c|c|c|c|}
\hline \multirow{2}{*}{ Observed } & \multicolumn{3}{|c|}{ Predicted } & \multirow{5}{*}{$\begin{array}{l}\text { Method: CHAID } \\
\text { Dependent variable: Individual } \\
\text { Job performance (Individual's self- } \\
\text { evaluations) }\end{array}$} \\
\hline & Low & High & Percentage of Success & \\
\hline Low & 40 & 106 & $27,4 \%$ & \\
\hline High & 17 & 142 & $89,3 \%$ & \\
\hline Total & $18,7 \%$ & $81,3 \%$ & $59,7 \%$ & \\
\hline
\end{tabular}

Figure 2 shows which countries are decisive for classifying employees, who are high and low, based on their own performance evaluation scores and the order of their importance.

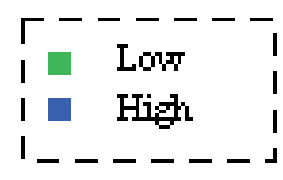

\begin{tabular}{|ccr|}
\hline \multicolumn{3}{|c|}{ Node 0 } \\
Categony & $\%$ & $\mathrm{n}$ \\
\hline Low & 47,9 & 146 \\
- High & 52,1 & 159 \\
\hline Total & 100,0 & 305 \\
\hline \multicolumn{4}{|c|}{ Nationality } \\
\hline
\end{tabular}

Adj. P-value $=0,000$, Chi-square $=26$,

$$
\text { 175. } d t=1
$$

\begin{tabular}{|c|c|c|}
\hline \multicolumn{3}{|c|}{ Node 1} \\
\hline Categony & 8 & $n$ \\
\hline Low & 19,4 & 12 \\
\hline 口 High & 80,6 & 50 \\
\hline Total & 20,3 & 62 \\
\hline
\end{tabular}

URraine, Fussia, Itaby,

Ethiopia

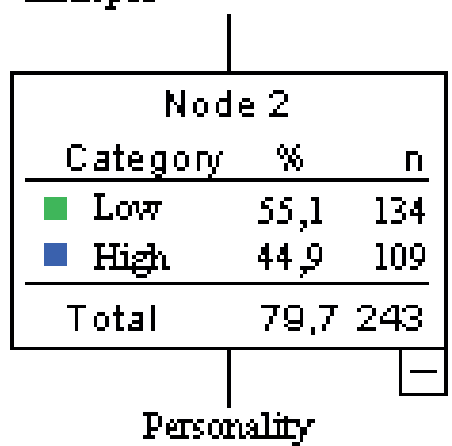

Adj. P-value=0,017, Chi-square=7.

636, $d t=1$

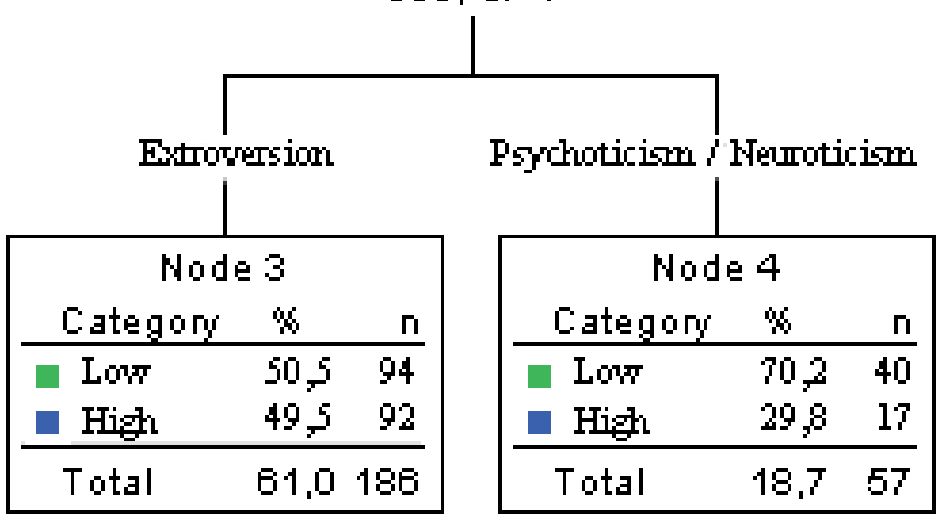

Figure 2: Decision Tree Model of IJP Based on Employees' Self-Evaluation 
When examining Figure 2 , it is seen that $47.90 \%$ of the 305 stage artists are classified as low and $52.10 \%$ as high. It is seen that the independent variable that best describes the performance is nationality with two sub-levels $(\chi 2=26.2, p<.05)$. When the sub-categories of the independent variable with the highest impact on performance are examined, it can be observed that 62 performers (50 high, 12 low) from Colombia, Cuba and Uzbekistan constitute node 1. Second node consists of those employees coming from Ukraine, Russia, Italy and Ethiopia. In this second node with a total of 243 individuals (109 high, 134 low), a sub-branch was characterized by personality traits and two different nodal points, and psychoticism-neuroticism $(\chi 2=7.6$, $\mathrm{p}<.05$ ). In a sub-branch for the second node, the extraversion is extracted as the third node (94 low, 92 high), and the psychoticism and neuroticism as the fourth node (40 low, 17 high). When the chi-square value is analyzed, it is seen that the best independent variable for explaining success is the country from where the employees come from $(\chi 2=26.2, p<.05)$ and the next one is the personality type $(\chi 2=7.6, p<.05)$. It is seen that the extroversion personality type is more effective in the classification of employee performance as high. As a result, it was determined that the performances of the extrovert employees coming from Ukraine, Russia, Italy and Ethiopia were higher.

Based on values from Table 5, first node was found to be the best node to distinguish between low and high-performance workers ( $n=50,31.4 \%)$. This is a cluster of 62 employees from Colombia, Cuba, Uzbekistan and $80.6 \%$ of which are classified as accurate. In order to determine the second-best node in the study, the gain values were examined and the third node was observed to be remarkable in terms of working performance ( $\mathrm{n}$ $=92,57.9 \%)$. This is the cluster in which 186 of the employees from Ukraine, Russia, Italy, Ethiopia with extrovert personality trait are classified as accurate by $49.5 \%$.

Table 5: Success Values Related to IJP

\begin{tabular}{ccccclll}
\hline \multirow{2}{*}{ Node } & \multicolumn{2}{c}{ Node } & \multicolumn{2}{c}{ Success } & Response & Index \\
\cline { 2 - 5 } & $\mathbf{n}$ & $\%$ & $\mathbf{n}$ & $\%$ & Rate & \\
\hline 1 & 62 & 20,3 & 50 & 31,4 & 80,6 & 154,7 \\
\hline 3 & 186 & 61,0 & 92 & 57,9 & 49,5 & 94,9 \\
\hline 4 & 57 & 18,7 & 17 & 10,7 & 29,8 & 57,2 \\
\hline
\end{tabular}

In the second model, where the individual's job performance is evaluated by their supervisors, summary information about the CHAID analysis is given in Table 6. According to this model, the dependent variable is IJP and independent variables are personality traits, gender, nationality, marital status, birth order. In this model, the assessment of IJP was conducted by the employees' supervisors. In cases where individual job performance is evaluated by the supervisors, results showed that nationality, gender and birth order can significantly predict the job performance as independent variables.

Table 6: Classification Table for Supervisor's Evaluations of IJP

\begin{tabular}{lcccl}
\hline \multirow{2}{*}{ Observed } & \multicolumn{3}{c}{ Predicted } & \\
\cline { 2 - 4 } & Low & High & $\begin{array}{c}\text { Success } \\
\text { Percentage }\end{array}$ & Method: CHAID \\
Low & 40 & 89 & $31,0 \%$ & $\begin{array}{l}\text { Dependent } \\
\text { Variable: }\end{array}$ \\
\cline { 2 - 4 } High & 20 & 143 & $87,7 \%$ & Individual Job \\
\cline { 1 - 2 } Total & $20,5 \%$ & $79,5 \%$ & $62,7 \%$ & $\begin{array}{l}\text { Performance } \\
\text { (Supervisor's } \\
\text { Evaluations) }\end{array}$ \\
\hline
\end{tabular}

As can be seen from Table 6, according to the supervisors, 40 (31.0\%) of 129 people with low employee performance were correctly classified by the study, while 89 (68.99\%) were actually classified as high performance despite poor performance. Similarly, 143 out of 163 people $(87.7 \%)$ were correctly classified by the program, but 20 people (22.27\%) were classified as unsuccessful despite being actually high performing. The overall success of our study in the classification of low- and high-performance employees is $62.7 \%$. The risk value of the system is $37.3 \%$ (1-62.7).

According to the supervisor's evaluation, the results of the analysis regarding the importance of the classification of the low and high-performance employees and their order of importance are shown in Figure 3. According to supervisors, $44.2 \%$ of employees are of low performance while $55.8 \%$ are with high performance $(\chi 2=18.9, p<.05)$. According to this, two sub-levels of nationalities can be derived. When we look at the sub-categories of the independent variables that best explain the performance situation, 232 people (143 high, 89 low) from Colombia, Ukraine, Cuba, Italy constitute the first node. The second node is Russia, Ethiopia, Uzbekistan consisting of 60 participants (20 high, 40 low). The first node performed a different sub-branch and gender was the determinant of this $(\chi 2=5.4, p<.05)$. At this level, the third node appeared as male with 134 persons (90 high, 44 low) and the 
fourth node as female with 98 persons ( 53 high, 45 low). Subsequent sub-branching occurs in the third node and the order of delivery was decisive here $(\chi 2=4.3$, $\mathrm{p}<.05)$. At this level, the fifth node shows 76 people (45 high, 31 low) who are first-born child, while the sixth node shows 58 people ( 45 high, 13 low) being later-born. When the chi-square value is analyzed, it is seen that the most independent variable explaining success is country from where participants are coming $(\chi 2=18.9, p<.05)$ followed by gender category $(\chi 2=5.4$, $p<.05)$. The third node is the birth order $(\chi 2=4.3, p$ $<.05)$. It is seen that the performance of the employees who are born in the second and subsequent places is more effective in the classification as high. As a result, it was determined that the performances of male workers coming from Colombia, Ukraine, Cuba and Italy were higher than those who were later-born.

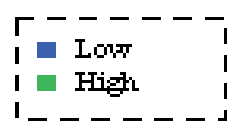

\begin{tabular}{|c|c|c|}
\hline \multicolumn{3}{|c|}{ Node 0} \\
\hline Categony & $\%$ & $n$ \\
\hline - Low & 44,2 & 129 \\
\hline - High & 55,8 & 163 \\
\hline Total & 100.0 & 292 \\
\hline
\end{tabular}

Adj. P-value=0,001, Chi-square=18. $957, d f=1$

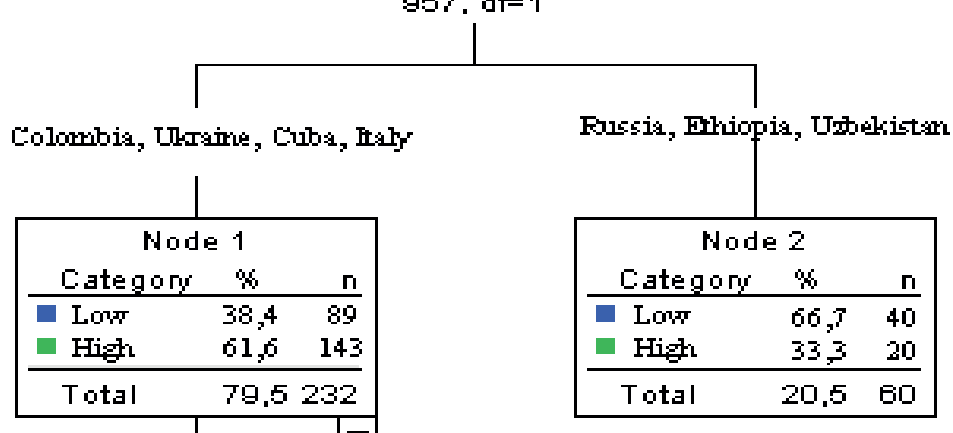

Adj. P-value $=0,020$, Chi-square $=5$.

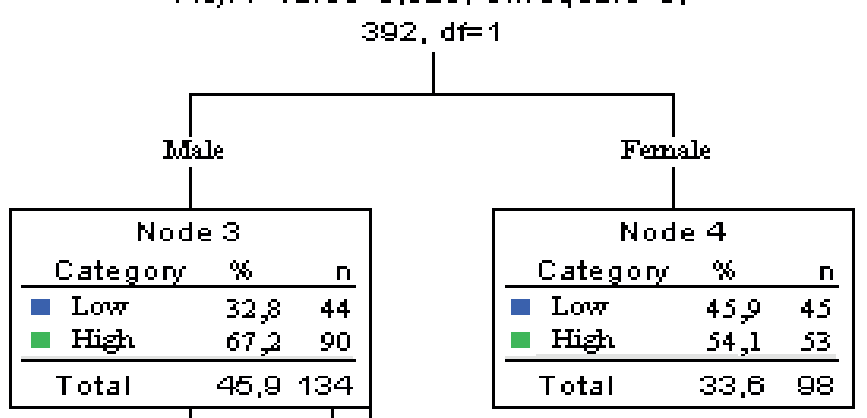

Birth order

Adj. P-value=0,037, Chi-square=4.

343, $d t=1$

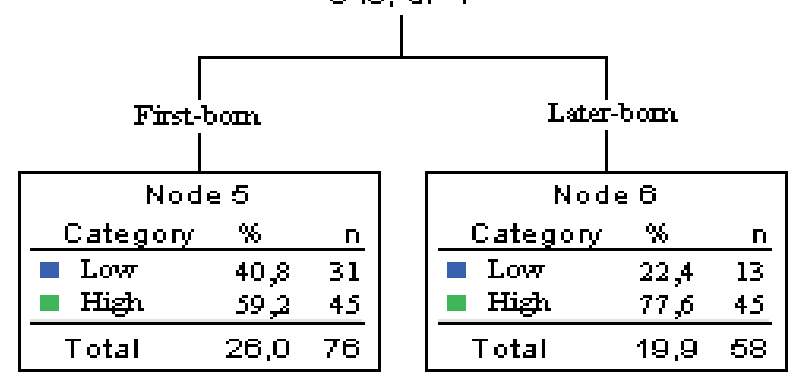

Figure 3: Decision Tree Model of IJP Based on Supervisor's Evaluation 
From the Table 7 it can be concluded that sixth node $(n=45, \% 27.6)$ is the best in differentiating low and high performing employees based on their supervisor's evaluations. This is a cluster of 58 employees who were later-born children coming from Colombia, Ukraine, Cuba, Italy with correct classification at 77.6\%. In order to determine the second best node, the gain values were examined and the fifth node was found to be remarkable in terms of working performance ( $\mathrm{n}$ $=45,27.6 \%)$. This is a cluster of 76 male workers from Colombia, Ukraine, Cuba, Italy, who were first-born children, and were correctly classified at $59.2 \%$. In addition, it is seen that the node that gives the least information in distinguishing employees' performances from supervisors' perspective is the second node $(n=$ $20,12.3 \%)$. This group consists of 60 people from Russia, Ethiopia, Uzbekistan and 33.3\% of them are classified correctly.

Table 7: Success Values Related to Supervisor's IJP Evaluations

\begin{tabular}{|c|c|c|c|c|c|c|}
\hline \multirow{2}{*}{ Node } & \multicolumn{2}{|c|}{ Node } & \multicolumn{2}{|c|}{ Success } & \multirow{2}{*}{$\begin{array}{c}\text { Response } \\
\text { Rate }\end{array}$} & \multirow{2}{*}{ Index } \\
\hline & $\mathrm{n}$ & $\%$ & $\mathrm{n}$ & $\%$ & & \\
\hline 6 & 58 & 19,9 & 45 & 27,6 & 77,6 & 139,0 \\
\hline 5 & 76 & 26,0 & 45 & 27,6 & 59,2 & 106,1 \\
\hline 4 & 98 & 33,6 & 53 & 32,5 & 54,1 & 96,9 \\
\hline 2 & 60 & 20,5 & 20 & 12,3 & 33,3 & 59,7 \\
\hline
\end{tabular}

Results show there is a difference between variables explaining the job performance of the employees when they do self-evaluation of their own performance than when the same is done by their supervisors (Figure 4).

\section{DISCUSSION}

Results of the CHAID analysis in the current study reveal that the effectiveness of certain factors and their importance levels differ according to the performance evaluation method. In case of self-evaluation, it can be concluded that employees with extrovert personality traits coming from Ukraine, Russia, Italy, and Ethiopia perform the best. When individual job performance is evaluated by the employee himself/herself, nationality can be considered as one of the factors affecting performance. Based on the analysis results it can be seen that the node where employees from Columbia, Cuba, Uzbekistan are clustered is successful in diversifying employees with high performance. In terms of job performance, second group of employees consists of those coming from Ukraine, Russia, Italy and Ethiopia with extraversion personality trait.

Based on the supervisors' evaluations, it can be concluded that highest performing employees come from Columbia, Ukraine, Cuba, and Italy, while male employees are performing better than female employees. In both supervisors' and employees' self-evaluations, employees from Columbia and Cuba are showing the highest performance levels. This finding showing the performance differences according to nationality is similar to the results of previous studies in the literature (Sekiguchi et.al., 2011; Diab \& Hazer, 2012). In addition, current study results showed there is the relation between birth order and performance according to supervisors' evaluation, indicating that later-born individuals are performing better.

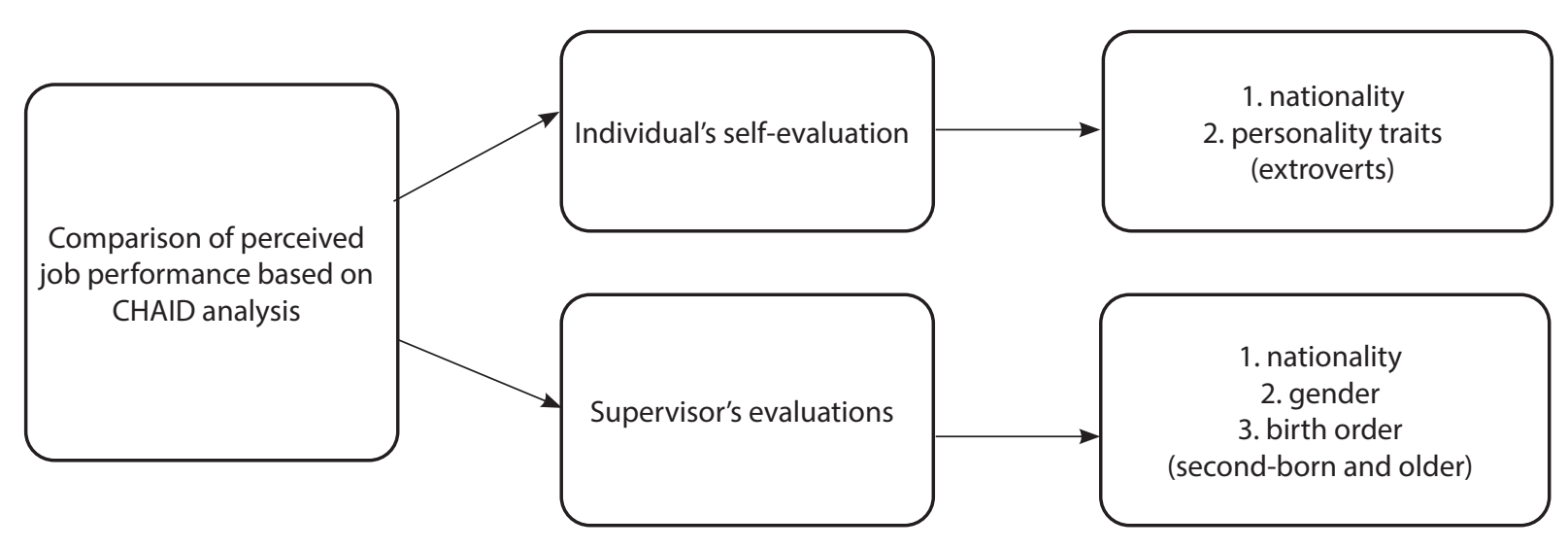

Figure 4: Model of CHAID Analysis 
The results of the study show that the variables that explain the performance of the individuals when they evaluate their own performance and the variables that explain the performance when evaluated by their supervisors are different. This result is consistent with three different meta-analysis studies in the related literature that found very low correlation between supervisor's and employees' self-evaluations of job performance (Harris \& Schaubroeck, 1988; Conway \& Huffcutt, 1997; Heidemeier \& Moser, 2009). Similarly, when we examine the importance of the variables explaining the performance, it turns out that there is a changing order according to the evaluator. When the importance order of the independent variables in the employees' self-evaluation is examined, personality differences come after the nationality, while this order in supervisors' evaluations starts with the nationality followed by gender and the order of birth variable respectively. This finding indicates that it is not easy to measure performance and make an accurate assessment.

Results of the current study prove the problematic nature of measurement of job performance. Goal of evaluating the individual's job performance is to obtain a multi-faceted perspective by evaluating the employees' performance as a whole and with all aspects.

\section{Theoretical implications}

Current study provides a significant contribution to the theoretical knowledge on IJP as it proved that use of biology traits theory is useful in the context of artists' performance, enhanced with the relevant propositions related to the effect of independent variables such as nationality, gender and birth order. CHAID analysis was used in revealing these variable results of different job performance measurement models. This innovative model, from which future studies on IJP can benefit on, is considered useful due to its possibility to easily observe the order of significance of the predictor variables on the dependent variables while deriving clear and understandable visual structures.

\section{Practical implications}

From practical managerial perspective the current study is valuable as it revealed that there may be differences in methods of measuring employee performance from different stakeholders' position. For this reason, multiple evaluation system can be proposed by using different methods in the same process in measuring and evaluating the performances of employees. Moreover, current study verifies that the personality dimensions of the employees should be taken into consideration in the selection of the employees in the performing arts companies, as well as in prediction of creativity and managerial performance during their career development. It is foreseen that the current study will contribute to the body of research conducted in the context of Turkey in the field of labor economy and psychology in organizations, allowing for its implementation in the other sectors as well. Similar studies among performing arts companies in other countries and/or other sectors, with a larger sample size and groups, will be useful in understanding the compatibility of the proposed theoretical frameworks in the context of global culture. The study will be beneficial for human resource professionals, employers and managers as it uncovers the relationship between the employee's personality traits and job performance. In addition, it shows that productivity can be achieved when the necessary measurements are used to address the effective performance of the employees.

\section{Limitations of the study}

There are several limitations of the current study as well, as this study is conducted in the specific region and among specific group of participants. Therefore, it is advisable to repeat this research design across several areas and, potentially, nationalities, in order to reach more generalizable results. The performance evaluated in this study is subject to an abstract evaluation since it is based on the artistic work. Therefore, the evaluation is complex as it differs from that evaluation of, for example, employees in the production process at a factory. At the same time, it is considered wrong for the supervisors to give the note 3 out of 5 at the Likert scale. This is due to the tendency of the chefs to give an average score instead of a high or low score because the employees do not deserve very low or very high scores during the evaluation (Lunenburg, 2012).

In addition, due to the nature of the current study, it is not possible to address the existence of the potential bias that evaluators, especially supervisors, may have when assessing employees' performance. The main purpose of this study was to determine the differences in IJP according to personality traits. In this way, the point of view that tends to see everyone below or below the average leads to measurement errors. On the other hand, when conducting evaluations, supervisors may tend to consider the time of evaluation rather than the whole process, as individuals do. The recall of the supervisors' recent performance and the tendency of employees to improve their performance 
during the evaluation periods affect the evaluation result (Lunenburg, 2012). Halo effect occurs when a general impression of the event or a person is created on the basis of a single characteristic (Phillips \& Gully, 2011). Accordingly, such supervisor's evaluations based on the appearance, personality traits or behaviors of the employees, can lead to the misleading impression that the performance of the employees is very good. In addition, in order to deeper analyze the reasons behind the founded differences in performance evaluation, several theoretical frameworks and assumptions may be used such as Hofstede's cultural dimension (Hofstede, Hofstede, \& Minkov, 2010) to explain the variability of results among different countries, or knowledge from social psychological field related to prejudice related-theories, actor-observer bias and similar (Aronson, Wilson, Akert, \& Sommers, 2016) can be applied. 


\section{REFERENCES}

Aboagye, A. K., Dai, B., \& Bakpa, E. K. (2020). The effect of risk communication on the nurses' task and contextual performance in disease outbreak control in Ghana: Application of the cause model. International Journal of Health Planning and Management. https://doi.org/10.1002/hpm.2978

Abubakar, T., Pangil, F., \& Othman, S. Z. (2016). Examining the link between HRM Practices and Employees' performance in Nigerian public sector. Management Science Letters, 6, 395-408. https://doi.org/10.5267/j.msl.2016.4.006

Akca, M., \& Yurtçu, B. G. (2017). Çalışma ortamı özelliklerinin hekimlerin görev ve bağlamsal performansına etkisi. International Journal of Academic Value Studies, 3(15), 197-207. https://doi.org/10.23929/javs.562

Aksu, G., \& Güzeller, C. O. (2016). Classification of PISA 2012 mathematical literacy scores using Decision-Tree Method: Turkey sampling. Egitim ve Bilim, 41(185), 101-122. https:// doi.org/10.15390/EB.2016.4766

Alfes, K., Truss, C., Soane, E. C., Rees, C., \& Gatenby, M. (2013). The relationship between line manager behavior, perceived HRM practices, and individual performance: Examining the mediating role of engagement. Human Resource Management, 52(6), 839-859. https://doi.org/10.1002/ hrm.21512

Ali-Hassan, H., Nevo, D., \& Wade, M. (2015). Linking dimensions of social media use to job performance: The role of social capital. Journal of Strategic Information Systems, 24(2), 65-89. https://doi.org/10.1016/j.jsis.2015.03.001

Allen, H. (2008). Using routinely collected data to augment the management of health and productivity loss. Journal of Occupational and Environmental Medicine, 50(6), 615-632. https://doi.org/10.1097/JOM.0b013e31817b610c

Allport, G. W. (1966). Traits revisited. American Psychologist, 21(1), 1-10. https://doi.org/10.1037/h0023295

Aronson, E., Wilson, T. D., Akert, R. M., \& Sommers, S. R. (2016). Social Psychology (9th ed.). London: Pearson Education.

Barclay, K. J. (2015). Birth order and educational attainment: Evidence from fully adopted sibling groups. Intelligence, 48, 109-122. https://doi.org/10.1016/j.intell.2014.10.009

Barrick, M. R., Mount, M. K., \& Strauss, J. P. (1993). Conscientiousness and performance of sales representatives: Test of the mediating effects of goal setting. Journal of $A p$, 78(5), 715-722.

Bennett, R. J., \& Robinson, S. L. (2000). Development of a measure of workplace deviance. Journal of Applied Psychology, 85(3), 349-360. https://doi.org/10.1037/00219010.85.3.349

Blickle, G. (1996). Personality traits, learning strategies, and performance. European Journal of Personality, 10(5), 337-352. https://doi.org/10.1002/(SICI)1099-0984
Bonesrønning, H., \& Massih, S. S. (2011). Birth order effects on young students' academic achievement. Journal of Socio-Economics, 40(6), 824-832. https://doi.org/10.1016/j. socec.2011.08.010

Borman,W.C., \& Motowidlo, S.J. (1993). Expanding the criterion domain To include elements of contextual performance. In N. Schmitt \& W. C. Borman (Eds.), Personnel selection in organizations. San Francisco: Jossey-Bass.

Bracken, D. W., Rose, D. S., \& Church, A. H. (2016). The evolution and devolution of $360^{\circ}$ feedback. Industrial and Organizational Psychology, 9(4), 761-794. https://doi.org/10.1017/ iop.2016.93

Brief, A. P., \& Motowidlo, S. J. (1986). Prosocial organizational behaviors. The Academy of Management Review, 11(4), 710. https://doi.org/10.2307/258391

Campbell, J. P. (1990). Modeling the performance prediction problem in industrial and organizational psychology. In M. D. Dunnette \& L. M. Hough (Eds.), Handbook of Industrial and Organizational Psychology (pp. 687-732). Palo Alto: Consulting Psychologists Press.

Campbell, J. P., McHenry, J. J., \& Wise, L. L. (1990). Modeling job performance in a population of jobs. Personnel Psychology, 43(2), 313-575. https://doi.org/10.1111/j.1744-6570.1990. tb01561.x

Cattell, R. (1979). Personality and learning theory. Vol. 1: The structure of personality in its environment. New York, NY: Springer.

Ceschi, A., Sartori, R., Dickert, S., \& Costantini, A. (2016). Grit or honesty-humility? New insights into the moderating role of personality between the health impairment process and counterproductive work behavior. Frontiers in Psychology, 7(1799), 1-11. https://doi.org/10.3389/fpsyg.2016.01799

Chamorro-Premuzic, T., \& Furnham, A. (2003). Personality predicts academic performance: Evidence from two longitudinal university samples. Journal of Research in Personality, 37(4), 319-338. https://doi.org/10.1016/ S0092-6566(02)00578-0

Conway, J. M., \& Huffcutt, A. I. (1997). Psychometric properties of multisource performance ratings: A meta-analysis of subordinate, supervisor, peer, and self-ratings. Human Performance, 10(4), 331-360. https://doi.org/10.1207/ s15327043hup1004_2

Costa, P. T., \& McCrae, R. R. (1988). Personality in adulthood: A six-year longitudinal study of self-reports and spouse ratings on the NEO Personality Inventory. Journal of Personality and Social Psychology, 54(5), 853-863. https://doi. org/10.1037/0022-3514.54.5.853

Craik, K. H. (1993). Fifty years of personality psychology. New York, NY: Plenum Press. 
Dåderman, A. M., Ingelgård, A., \& Koopmans, L. (2020). Cross-cultural adaptation, from Dutch to Swedish language, of the individual work performance questionnaire. Work, 65(1), 97-109. https://doi.org/10.3233/WOR-193062

Demirok, A. (2018). Örgütsel sinizm ve iş performansı arasındaki ilişki: Diyarbakır'da çalışan kadrolu ve sözleşmeli personel örneği(Unpublished master's thesis). Türk Hava Kurumu Üniversitesi, Ankara.

Diab, D. L., \& Hazer, J. T. (2012). Effect of rater nationality on the relationships among ratee task, contextual, and counterproductive behaviors and salary estimates. International Journal of Selection and Assessment, 20(3), 359-375. https:// doi.org/10.1111/j.1468-2389.2012.00606.x

Escorpizo, R. (2008). Understanding work productivity and its application to work-related musculoskeletal disorders. International Journal of Industrial Ergonomics, 38(3-4), 291-297. https://doi.org/10.1016/j.ergon.2007.10.018

Eysenck, H. J. (1967). The biological basis of personality. Springfield, IL: Thomas.

Fayers, P. M., \& Hand, D. J. (2002). Causal variables, indicator variables and measurement scales: an example from quality of life. Journal of the Royal Statistical Society, 165(2), 233-261. https://doi.org/10.1111/1467-985X.02020

Francis, L. J., Brown, L. B., \& Philipchalk, R. (1992). The development of an abbreviated form of the revised Eysenck personality questionnaire (EPQR-A): Its use among students in England, Canada, the U.S.A. and Australia. Personality and Individual Differences, 13(4), 443-449. https:// doi.org/10.1016/0191-8869(92)90073-X

Galton, F. (1874). English men of science: their nature and nurture. London: Macmillan.

Gliner, J. A., Morgan, G. A., \& L, L. N. (2017). Research methods in applied settings: An integrated approach to design and analysis. New York, NY: Taylor \& Francis.

Gözel, G., Atmaca, G. D., \& Durat, G. (2017). Hemşirelerin kişilik özellikleri ile iş performansları arasındaki ilişkinin değerlendirilmesi. Kocaeli Üniversitesi Sağlık Bilimleri Dergisi, 3(1), $11-16$

Harris, M. M., \& Schaubroeck, J. (1988). A meta-analysis of self-supervisor, self-peer, and peer-supervisor ratings. Personnel Psychology, 41(1), 43-62. https://doi. org/10.1111/j.1744-6570.1988.tb00631.x

Hashmi, F., Ameen, K., \& Soroya, S. (2019). Does post graduate degree make any difference in job performance of information professionals? Library Management, 41(1), 14-27. https://doi.org/10.1108/LM-07-2019-0042

Heidemeier, H., \& Moser, K. (2009). Self-other agreement in job performance ratings: A meta-analytic test of a process model. Journal of Applied Psychology, 94(2), 353-370. https://doi.org/10.1037/0021-9010.94.2.353
Hertwig, R., Davis, J. N., \& Sulloway, F. J. (2002). Parental investment: How an equity motive can produce inequality. Psychological Bulletin, 128(5), 728-745. https://doi. org/10.1037/0033-2909.128.5.728

Hofstede, G., Hofstede, G. J., \& Minkov, M. (2010). Cultures and organizations: Software of the mind (Rev. 3rd). New York, NY: McGraw-Hill.

Horner, S. B., Fireman, G. D., \& Wang, E. W. (2010). The relation of student behavior, peer status, race, and gender to decisions about school discipline using CHAID decision trees and regression modeling. Journal of School Psychology, 48(2), 135-161. https://doi.org/10.1016/j.jsp.2009.12.001

lacovou, M. (2008). Family size, birth order, and educational attainment. Marriage and Family Review, 42(3), 35-57. https://doi.org/10.1300/J002v42n03_03

Judge, T. A., Thoresen, C. J., Bono, J. E., \& Patton, G. K. (2001). The job satisfaction-job performance relationship: A qualitative and quantitative review. Psychological Bulletin, 127(3), 376-407. https://doi.org/10.1037/0033-2909.127.3.376

Karancı, N., Dirik, G., \& Yorulmaz, O. (2007). Eysenck kişilik anketi-gözden geçirilmiş kısaltılmış formunun (EKA-GGK) Türkiyede geçerlik ve güvenilirlik çalışması. Türk Psikiyatri Dergisi, 18(3), 254-261.

Keleş, K. (2017). Etkileşimci ve dönüşümcü liderliğin işten ayrılma niyeti ve iş performansına etkisi(Unpublished master's thesis). Cumhuriyet Üniversitesi, Sivas.

Koopmans, L. (2014). Measuring individual work performance. Zutphen: CPI Koninklijke Wöhrmann.

Koopmans, L., Bernaards, C., Hildebrandt, V., Van Buuren, S., Van Der Beek, A. J., \& de Vet, H. C. w. (2012). Development of an individual work performance questionnaire. International Journal of Productivity and Performance Management, 62(1), 6-28. https://doi.org/10.1108/17410401311285273

Lunenburg, F. C. (2012). Organizational structure: Mintzberg's framework. International Journal of Scholarly, Academic, Intellectual Diversity, 14(1), 1-8.

Mael, F. A., O'Shea, P. G., Smith, M. A., Burling, A. S., Carman, K. L., Haas, A., \& Rogers, K. S. (2010). Development of a model and measure of process-oriented quality of care for substance abuse treatment. Journal of Behavioral Health Services and Research, 37(1), 4-24. https://doi.org/10.1007/ s11414-009-9180-4

Maltby, J., Talley, M., Cooper, C., \& Leslie, J. C. (1995). Personality effects in personal and public orientations toward religion. Personality and Individual Differences, 19(2), 157-163. https://doi.org/10.1016/0191-8869(95)00036-6

Metin, U. B., Peeters, M. C. W., \& Taris, T. W. (2018). Correlates of procrastination and performance at work: The role of having "good fit." Journal of Prevention \& Intervention in the Community, 46(3), 228-244. https://doi.org/10.1080/1085 2352.2018.1470187 
Motowidlo, S. J., \& Van Scotter, J. R. (1994). Evidence that task performance can be distinguished from contextual performance. Journal of Applied Psychology, 79(4), 475-480. https://doi.org/10.1037/0021-9010.79.4.475

Mumford, M. D., \& Gustafson, S. B. (1988). Creativity syndrome: Integration, application, and innovation. Psychological Bulletin, 103(1), 27-43.

Nadatien, I., Handoyo, S., Pudjirahardjo, W. J., \& Probowati, Y. (2019). The influence of organizational pride on the performance of lecturers in health at the Nahdlatul Ulama university in Surabaya. Indian Journal of Public Health Research and Development, 10(1), 538-542. https://doi. org/10.5958/0976-5506.2019.00105.0

Pallegama, R. W., Ariyasinghe, S., \& Perera, H. A. D. (2007). Influence of personality traits on the attitudes towards the teaching program and the academic performance of dental undergraduate. Proceedings of the Peradeniya University Research Sessions, 12(1), 126-127.

Phillips, J. M., \& Gully, S. M. (2011). Organizational behavior: Tools for success. Natorp Boulevard: South-Western Cengage Learning.

Podsakoff, P. M., \& S.B., M. (1989). A second generation measure of organizational citizenship behavior. Bloomington: Indiana University.

Poropat, A. E. (2011). The Eysenckian personality factors and their correlations with academic performance. British Journal of Educational Psychology, 81(1), 41-58. https:// doi.org/10.1348/000709910X497671

Price, J. (2008). Parent-child quality time: Does birth order matter? Journal of Human Resources, 43(1), 240-265. https:// doi.org/10.3368/jhr.43.1.240

Rothmann, S., \& Coetzer, E. P. (2003). The big five personality dimensions and job performance. Journal of Industrial Psychology, 29(1), 68-74. https://doi.org/10.4102/sajip. v29i1.88

Sato, T. (2005). The Eysenck personality questionnaire brief version: Factor structure and reliability. Journal of Psychology: Interdisciplinary and Applied, 139(6), 545-552. https://doi. org/10.3200/JRLP.139.6.545-552

Schultz, D. P., \& Schultz, S. E. (2017). Theories of personality (11th ed.). Boston: Cengage Learning.

Sekiguchi, T., Bebenroth, R., \& Li, D. (2011). Nationality background of MNC affiliates' top management and affiliate performance in Japan: knowledge-based and upper echelons perspectives. The International Journal of Human Resource Management, 22(5), 999-1016. https://doi.org/1 0.1080/09585192.2011.556774
Sinclair, R. R., \& Tucker, J. S. (2006). Stress-CARE: An integrated model of individual differences in soldier performance under stress. In A. Adler, T. Britt, \& C. Castro (Eds.), Military life: The psychology of serving in peace and combat: Vol. 1 military performance (pp. 202-231). Westport: Greenwood Publishing Group.

Smith, C. A., Organ, D. W., \& Near, J.P. (1983). Organizational citizenship behavior: Its nature and antecedents. In Journal of Applied Psychology (Vol. 68).

Tett, R. P., Guterman, H. A., Bleier, A., \& Murphy, P. J. (2000). Development and content validation of a "hyperdimensional" taxonomy of managerial competence. Human Performance, 13(3), 205-251. https://doi.org/10.1207/ S15327043HUP1303_1

Thorndike, R. L. (1949). Personnel selection: Test and measurement techniques. New York, NY: Wiley.

Turkish Hoteliers Federation - TUROFED (2019). Toursim Report. 2019/1 https://www.turofed.org.tr/_files/_pdf/ RAPOR/turofed-turizm-raporu-2019.pdf

Uppal, N. (2014). Moderation effects of job characteristics on the relationship between neuroticism and job performance. International Journal of Selection and Assessment 22(4), 411-421. https://doi.org/10.1111/ijsa.12087

Van Scotter, J. R., \& Motowidlo, S. J. (1996). Interpersonal facilitation and job dedication as separate facets of contextual performance. Journal of Applied Psychology, 81(5), 525-531. https://doi.org/10.1037/0021-9010.81.5.525

Viswesvaran, C. (2002). Assessment of individual job performance: A review of the past century and a look ahead. In N. Anderson, D. S. Ones, H. K. Sinangil, \& C. Viswesvaran (Eds.), Handbook of industrial, work and organizationalpsychology, Volume 1: Personnel psychology. Thousand Oaks, CA: SAGE Publications.

Viswesvaran, Chockalingam, \& Ones, D. S. (2000). Perspectives on models of job performance. International Journal of Selection and Assessment, 8(4), 216-226. https://doi. org/10.1111/1468-2389.00151

Yeşilyaprak, B. (2012). Mesleki rehberlik ve kariyer danışmanlığı kurumdan uygulamaya. Ankara: Pegem Akademi

Zhao, S., Liu, Y., \& Zhou, L. (2020). How does a boundaryless mindset enhance expatriate job performance? The mediating role of proactive resource acquisition tactics and the moderating role of behavioural cultural intelligence. International Journal of Human Resource Management 31(10), 1333-1357. https://doi.org/10.1080/09585192.20 16.1253033 